\title{
The (Im)possibility of Guilt - A Psychoanalytic Exploration Around Nazi Guilt ${ }^{1}$
}

\author{
David Figueirôa ${ }^{2}$ \\ PsiRelacional, Lisboa, Portugal
}

\begin{abstract}
Through the fantastic story told by Momik, grandson of Jews deported to a Nazi extermination camp, we will reflect about Nazi guilt, evidencing the contrast of the role of guilt in Freudian human civilization and Hitler's Nazi project. The double nature of guilt in psychoanalysis is shown using León Grinberg's notions (persecutory guilt / depressive guilt) and we then reach the idea of a retroactive guilt. The article points to the figure of Adolf Eichmann, the man in charge of the Nazi "final solution", the submissive employee revealed by Hanna Arendt, who here finds psychoanalytic meaning.
\end{abstract}

Key Words: Guilt, Nazi guilt, culture, submissive, Eichmann, Arendt, Grossman.

A través de la fantástica historia contada por Momik, nieto de Judios deportados a un campo de exterminio nazi, vamos a reflexionar sobre la culpabilidad nazi, lo que evidencia el contraste de la función de la culpa en la civilización humana freudiana y el proyecto nazi de Hitler. La doble naturaleza de la culpa en el psicoanálisis se muestra con las nociones de León Grinberg (culpa persecutoria / culpa depresiva) para luego llegar a la idea de un sentimiento de culpa retroactiva. El artículo señala que la figura de Adolf Eichmann, el hombre a cargo de la "solución final" nazi, el empleado sumiso revelado por Hanna Arendt, encuentra sentido psicoanalítico.

Palabras clave: Culpa, Culpa Nazi, Cultura, Sumisión, Eichmann, Arendt, Grossman.

Título en castellano: La (Im)posibilidad de la Culpa - Una exploración psicoanalítica en torno a la culpa nazi

Cita bibliográfica / Reference citation:

Figueirôa, D. (2016). The (Im)possibility of Guilt - A Psychoanalytic Exploration Around Nazi Guilt. Clínica e Investigación Relacional, 10 (1): 191-202. [ISSN 1988-2939] [Recuperado de www.ceir.info ] DOI: $10.21110 / 19882939.2016 .100112$

\footnotetext{
${ }^{1}$ Communication presented at colloquium "A Culpa [On Guilt]", IARPP Portugal, Lisbon, 30 October 2014.

${ }^{2}$ Psychonanalytical psychotherapist, vice-president of PsiRelacional - Associação de Psicanálise Relacional (Portugal), member of IARPP Portugal.
} 


\section{The story-teller who won't die}

The story was told to me by the grandson. His grandparents were Jews who had been deported to a Nazi extermination camp, during World War II. The story Momik told me of his grandfather, Anshel Wasserman, is a fantastic one. It was perhaps through it that I understood something about Nazi guilt: that it was, in fact, an impossibility.

It is a terrible story: the grandfather, Anshel Wasserman, saw his family (wife and daughter) brutally murdered in front of him, just as they arrived at the Nazi camp. He survives, goes to work for the "dentists", who were the ones who removed teeth from the dead, until the inevitable day comes when he too goes to Himmelstrasse, the path to heaven, as the Nazis called it. This is when the unexplainable happens, the absurd: the Nazis try to kill this Jew and they can't, it was impossible to eliminate him. They tried with a shotgun, they tried inside the truck, they tried the gas chambers, and he didn't die. He was taken to the commander of the camp, the Obersturmbannführer Neigel, who shoots the grandfather again with a revolver through the forehead. "A sort of buzz went through my head, from ear to ear", the grandfather Anshel would one day recount. The Nazi was, of course, perplexed: "Are you mocking me?" he cries. But no, the Jew didn't want to disturb him, he too was feeling embarrassed, not able to understand why he would not succumb. It was worse for the Nazi, of course: a Jew who wouldn't die, an absurdity and an unacceptable precedent. The Führer would be furious!

They didn't know what to do with him. Grandfather Anshel was put under commander Neigel's watch, as a gardener for the Nazi who had executed his family. Meanwhile, the Nazi recognized him as the well-known writer of children's stories, "The Children of the Heart", which he had read in his childhood. He then asked Anshel to tell him a special story, for him alone. Something to occupy his mind after his work in the camp.

Anshel Wasserman refuses to tell the story to "Herr Neigel" (Mr. Neigel). The Nazi, without death as an argument, is left without arguments. But the Jew, tired, stripped of himself and of his own people, gives vent to his feelings: "I ardently wish to die". Faced with the Jew's weakness, Herr Neigel wins back his argument and says to him: "Every night, when you finish telling me the day's episode, I will try to kill you. One bullet in the head. That will be your reward. (...) I will shoot at you every night on the condition, of course, that the story is good".

\section{Guilt and Culture}

Nazi indifference towards the value of human life is shocking. The organized process of cruelly mass-murdering other human beings is shocking. The Holocaust is an Absurdity. 6 
million Jews were annihilated, about two thirds of those living in Europe at the time. Around 1 million children, two million women and three million men. Taking into consideration also the mass murders of civilian and war prisoners, homosexuals, handicapped people and gipsies, the number of victims of the extermination program alone was between 10 and 11 million people (US Holocaust Memorial Museum). This mass killing, this organized Nazi destruction provided an opportunity and a cloak for many psychopaths and perverts. We cannot forget, for instance, Amon Göth, the commander at Plaszow's extermination camp, played by Ralph Fiennes in the movie "Schindler's List" (by Steven Spielberg, 1993). But the Nazi procedural order is a greater network than the individual elements of its disturbed protagonists and is itself a generator of Evil (and not just one of its expressions). This was shown to us by Hannah Arendt, with her theory on the banality of evil and the bureaucratization of violence, from the study on the "employee" Adolf Eichmann, the chiefexecuter of the final solution for the extermination of the Jewish people in Nazi Europe (Arendt, 1963, 1951). Eichmann was a family man, a father, an exemplary and dedicated worker, as was, moreover, the camp commander in our story, Herr Neigel.

Where is these men's guilt? We have seen how Eichmann, like so many other Nazis, shows no signs of it. And neither are clear signs of psychopathic, psychotic, perverse or anti-social disturbances found in him or in his story. He is a man of baffling banality.

Adolf Hitler once said that "Nature is cruel; therefore we are also entitled to be cruel. When I send the flower of German youth into the steel hail of the next war without feeling the slightest regret over the precious German blood that is being spilled, should I not also have the right to eliminate millions of an inferior race that multiplies like vermin? (quoted by Fest, 1973, p.679680). Cruelty is taken as a natural force of man. And Hitler removes the guilt from the man subject to cruelty. Cruelty is not guilty, it is a natural expression of strength and superiority. A guilty conscience belongs to the Jews, as a sign of their weakness. Jews feel guilt, Nazis don't feel guilt.

As an absolute contrast to this line of thinking, the Jew Sigmund Freud had stated that "moral consciousness" was a fundamental acquisition of man. Of man as subject of his personal story, seeking balance between the pulsational force and the prohibiting law, individual desire and collective interest, between the Ego and the Superego; but also an acquisition by Man as a subject of human History - in Freud, guilt actually establishes religion, social organization and culture, as is made clear in "Totem and Taboo" (1913), an emerging and organizing guilt after the assassination of the primeval father. The primeval (the Oedipal father), the absolute tyrant of the horde where he kept all the women to himself, is murdered and then eaten by his children, so that they get rid of him and so that they identify with him. 
After the hatred is satisfied, the guilt that would give rise to totemism emerges (given the affective ambivalence), a kind of repairing glorification of the father (also at the basis of future religions). Also a new social order emerges, based on the cooperation of brothers and the rigorous sharing of women, through the rule "thou shall not kill" (at a first instance, the totem animal, at the extreme, you shall not repeat the parricide act) and of the institution of prohibiting incest and, therefore, of the institution of exogamy and trade with other clans, with the outside.

In other texts, such as "Civilization and its Discontents" (1930), Freud would develop the concept of the role of guilt in the balance of civilization, with its repressing role regarding aggressive tendencies. Indeed, in that text Freud somehow anticipates what would come to the world, such as; "Man is not just a gentle creature that needs love, who would only defend himself when attacked, but, on the contrary, he is endowed with impulses which include a great deal of aggressiveness", for "Man is a wolf to man" ("Homo homini lupus"), which refers to the death drive and its eternal struggle with the life drive, which for Freud are both constituent parts of being human.

Hitler eliminated guilt from his Nazi project, as Freud revealed it as fundamental to human civilization and culture.

For Freud, the feeling of guilt is a nuclear and structuring element of the relationship between man and the other and of social construction. There is no Culture without guilt.

\section{Persecutory guilt and depressive guilt}

"I am guilty" is one of the most characteristic human psychisms, conscious or unconscious. Guilt occupies a central place in psychic life and its nature and calibration on psychic economy influences the formation of feelings as important as responsibility toward others and the feeling of internal freedom itself. Generically we can think, for instance, that the greater the guilt (when in excess) the lesser the degree of psychic freedom a person has (the person limits him/herself, is persecuted and conditioned by their own guilt) but also if there isn't enough guilt acting on the person's psychic economy, their level of responsibility will be limited (an ability to feel "reasonable guilt" is one of the founding elements of a sense of responsibility and of the relation with the other).

When guilt is off-balance, responsibility is constricted, freedom is bound up, neurotic (oedipal) guilt manifests itself, and the subject seeks punishment, such as through criminal action, as shown by Freud. 
In other words, guilt, as a concept, needs a balance, for if it exists in excess or if it does not exist in sufficient quantity it can unbalance human psychic life. But it could be said that there is no such thing as insufficient guilt, there is always too much. The true imbalance of guilt is excess, and paradoxically one of the expressions of this excess is its apparent absence. Excessive guilt, which can be camouflaged by absence of guilt.

Our inspiration for this statement comes from the concept of guilt proposed by León Grinberg (1963), based on the work of Melanie Klein and other studies on early development. Guilt is considered a broad phenomenon in the human mind. At an early stage persecutory guilt (situated at Klein's paranoid-schizoid position) is differentiated from depressive guilt, which appears at a later stage (related to the Kleinian depressive position, therefore being a posterior acquisition, "transformed" from the first - and closer to Freudian guilt).

This "depressive guilt" derives from the psychic constitution of the whole object and from the integration of the ambivalent affections that are directed at it. It is the guilt that arises with the feeling of having done harm to the good object (in reality or phantasy), a feeling that is at the basis of the reparation movement, which is a fundamental acquisition for the development of psychic and relational life. To repair the object, which survives, which remains, is to be able to remain in relation. This notion of guilt is also closer to the guilt conceptualized by Freud, and to a large extent is the result of conflicting tensions between the Ego and the Superego (we could also say between desire and "moral consciousness", a term, moreover, initially coined by Freud). For Freud, however, the moment of its acquisition tended to occur later, as a result of Oedipus and the formation of the Superego.

The Kleinian concept is even closer to Ronald Fairbairn's, which situates the emergence of guilt in the same period, calling it a "moral defense" (1943), thus evidencing the relational and moral nature of guilt. Guilt is related to the integration of good and evil (which before were separated) and allows for psychism, from then on, to defend itself from what before was an absolute feeling - a kind of "absolute guilt" - prior to a sense of moral. That "absolute guilt", in the earlier psychism, would reflect a radical, unconditional sense of self, which we could translate as "I am evil", "I am totally evil", therefore, "I am guilty and can be nothing but guilty". The acquisition of the moral defense connects the sense of evil to a morality, hence freeing the subject from absolute badness: the absolute "I am evil" becomes a conditional "I am evil", close to "I was evil", which means "I can be good" if "I do good", if I come to correspond to the demands of the moral instance. I can then become not guilty, be un-guilted and a path of hope is opened up (as Winnicott also pointed out, 1966) and, ultimately, of maintaining and gaining back love. Fairbairn thus differentiates "moral 
defense", which is simultaneous to Kleinian depressive guilt, from this earlier radical feeling, the "absolute guilt or evil" - or "persecutory guilt" in Klein's terms.

"Persecutory guilt" is of an absolute and unconditional nature, it has no escape. Klein mentions a precocious guilt, for instance, in "Envy and Gratitude" (1957), as a consequence of an excess of envy (itself a consequence of a prevalence of the "death drive" within the subject's psychism, to the detriment of the "life drive"), a guilt "experienced by an ego not yet capable of tolerating it", thus making it "felt as a persecution and the object that awakens it a persecutor" and that can "fail to elaborate the depressive position as a consequence". This persecutory guilt would then be associated to an even more frail and immature Ego and would be intensified by the anguishes of the paranoid-schizoid phase and the frustrations and failures in accessing the depressive position.

Persecutory guilt doesn't have, in itself, either the appearance or the substance of guilt, since it is pre-moral, and since there isn't, yet, a good-bad integration. This is why, in that "position", the object also cannot be fixed, only appeased, controlled, moved away or, at the limit, destroyed.

\section{The retroactivity of guilt}

We have clarified the concept of guilt that we use here, which has been separated into persecutory guilt and depressive guilt. The former is generated at the origin of human relations, and is the originator of psychism. The latter is acquired in the transition between the paranoid-schizoid position and the depressive position.

When we differentiate between persecutory guilt and depressive guilt we come face to face with the dual nature of guilt, excessive guilt, which is tyrannical and absolute versus conditional guilt, which is potentially healing and which has a relational construction.

We believe that the idea of an "absence of guilt" can only be applied to depressive guilt, when it is not constituted, but not to persecutory guilt, which is inescapable, given the schizoid basis of human psychism (Fairbairn, 1940; Klein, 1946).

For guilt to be experienced as such, acquisition would be needed of what was already depressive guilt. Fairbairn helps us also to understand that the only form of a moral sense is an integrated and depressive one, because there is no moral if there is only evil, or if evil is completely disconnected from good.

In line with what we said above, and if we were to support a linear perspective of development, we would advocate that the word "guilt" should be dropped from the phrase 
"persecutory guilt" - it would perhaps be more correct to speak of a "persecutory wickedness", derived from introjective-projective games of the first relationship with the mother, in particular, the experience of deprivation and frustration. But taking into account the psychic dynamics and the oscillations between the paranoid-schizoid and depressive registers, i.e., the oscillation between progredient and regressive movements in the human mind (movements that occur constantly, as shown in Klein and Bion), the concept of "precocious guilt" makes sense. Guilt is experienced retroactively in a regressive movement, through the experience of depressive guilt - gained in the meantime - either as a mere outline or properly constituted. In either case, faced with regressive movements, the experience of a moral sense and depressive guilt would be impregnated into the mind, establishing a restructured reading (unconscious) of paranoid-schizoid evil. In the regressive movement, depressive guilt as such would be diluted by the re-emergence of paranoidschizoid dynamics but also inflated and distorted by the feeling of one's own wickedness rising from the bottom of the paranoid-schizoid cauldron. This distortion of depressive guilt could constitute a "persecutory guilt". We thus believe that regressively, persecutory wickedness takes the form of persecutory guilt - and the word guilt is properly applied.

\section{The story continues}

Meanwhile, every evening the Jew Anshel Wasserman continued to tell the story to the commander of the Nazi death camp, Herr Neigel. At the end of each evening, the Nazi fired a shot into the head of the writer.

We know, therefore, 1) that the Jew still did not die, 2) that the Nazi was enjoying the story.

\section{Kill or be killed}

Let us return to the two archetypical representations of death camp commanders, Goth, "the psychopath" and Eichmann, "the employee".

The profile of the former (Goth) shows clear evidence of a paranoid-schizoid disorder, with persecution dynamics, which transform the persecuted into the persecutor and in which omnipotence, superiority, arrogance, mockery and triumph over others cover an uncontrollable urge for destruction. It is a profile dominated by power, a destructive and tyrannical power over others.

The second profile (Eichmann), unveiled by Hannah Arendt in 1963, is more enigmatic. This is a profile marked by submission and over-adaptation to reality and the absence of any 
manifestations of disturbance, with the exception of that which is specifically associated with carrying out his function: to eliminate, to kill. And this is not done of his own initiative, but through subjection to the order and system of the time. Eichmann's defense statements during his trial are extraordinary: he showed no remorse and a full belief in his sense of duty, an unshakable conviction in the world order that he had embraced. The problem, which is ours, in our view, is that the order was changed, perverted, and that distortion became the ruling order, the universal power in Nazi Germany.

Eichmann, a zealous and competent employee, is effective but not creative, he does not, in fact, think. Thought was replaced by the tyrannical and unique ideology, like in Orwell's "1984". Eichmann is a part of the Nazi apparatus; the boundaries between the individual and the collective are cancelled and subjectivity fades to give place to impersonal and mechanical bureaucracy. Subjectivity is not valued, neither in the other, nor in oneself.

We believe that in this kind of personality, which is more common than is believed, the depressive position has been organized in relatively thick but superficial zones of the self. The self is sufficiently imbued with depressive learnings, to the point of being able to promote an apparent and sustainable balance with the outside world. But a narrow and hidden area of the self itself will not have reached full human development. This is an "unpopulated" area of the self, or an interior place which is "not recognized", "unconfirmed", not "subjectified" (in the sense of "unvalidated unconscious", in the words of Orange, Atwood and Stolorow, 1997). An area compensated by objects taken from the reference system, ideals, higher orders. It constitutes an identity substitute that eliminates thought and conflict. To think, to connect, to feel, to create, may generate a disturbing disorder, as these acts take place upon an empty interior, where one may fall if one is not sure of one's step. Becoming part of the homogeneous and hegemonic system, which is powerful and free of conflicts, provides that external security and the indoor-outdoor collage offers an internal illusion of security. It is especially necessary in times as binary as the Nazi ones, where "those considered inferior" were exterminated outright. As the saying goes, a good expression of a paranoid-schizoid wisdom: "kill or be killed."

Eichmann is a parasite on the system and the system is a parasite on Eichmann. The post of commander of the Nazi death camp provided a cloak and an excellent armour for this type of mechanical and submissive personality - and also gave coverage to the psychopath. But the submissive and exemplary employee offers additional guarantees of accuracy and effectiveness, which are not offered by the psychopath, especially if he has a disturbed mind, given to excesses, and dizzied by power. In the case of the submissive employee, his requirements are combined with the demands of an organized system (Ciccone, 2003 from 
Meltzer, 1968. We ourselves have explored the link between tyranny and submission and between tyranny and evil, Figueirôa, 2014).

What moves a submissive person is not power over others, as in psychopathic dynamics. There, the power seeks to reverse the humiliation once felt against the adult abuser. What moves a submissive person is being able to exist, to have a place. He perhaps seeks compensation for the indifference with which he was treated in childhood by the adult, who was unable to recognize and to subjectify in tune with and in articulation with the subject's "true self", in Winnicott's words.

Returning to guilt, in normal social circumstances, this type of subject fits in and copes with the dominant moral judgment without apparent failures or disturbances. Under an ideological totalitarian and homogeneous regime, the moral order of the subject completely subscribes to the moral order of the new system. The subject's guilt is completely subsidiary. Eichmann's sense of guilt would have been greater if he had not carried out his duty.

But there would be no evidence of absence of guilt if the system had not been defeated. If, by some terrible chance, today we were all Nazis, Eichmann would be one of us. And the Jews and all others would be to blame.

Basically, here there is no absence of guilt, there is a shift of the moral order, internalized and assimilated to the self. Hannah Arendt's banality of evil finds a potential psychoanalytic meaning in this possibility.

\section{Moral of the story}

And how does the story of Momik end? Anshel Wasserman continued to tell stories to the Nazi, but he was motivated by a secret plan: his purpose was to transform the Nazi into a human being through human speech; and through subjectivity and human relationship break down the statistics and the efficiency of the Nazi machine. But his aim was not altruistic. The Nazi officer and the system had killed his wife and his daughter at close range. Wasserman believed that breaking down the Nazi structure and infiltrating it with humanity would necessarily lead to its destruction. At the end of the story, the Nazi, Herr Neigel, shot himself in the head and died.

This story, told by Momik, is an excerpt adapted from the third chapter of the masterpiece by the Israeli Jew, David Grossman, "See Under: Love" (1986). Here I pay my tribute to him and to literature in general, as an expression of Beauty and Humanity. 
In this story, the moral order shifted from the inhuman Nazi to the order of human relationships. This is unbearable for the Nazi. Here, in this literary vignette, we have before us a perfect example of the impossibility of guilt. When guilt is experienced, the subject commits suicide.

Fairbairn (1943) alerted us to clinical sensitivity regarding the issue of over-hasty awareness of guilt in the analytic relationship (which is a metaphor in our story): to raise or to unveil the patient's guilt may, in some circumstances, break the defenses of the subject and - if he survives the demons released - may lead to reinforcement of repression of bad objects and a negative therapeutic reaction.

Before we finish it is important to show the fundamental difference between Nazi guilt and German guilt. If we consider the depressive and moral dimension of guilt, Nazi guilt, the idea at the base of this article, is a contradiction in terms, as Hitler himself said. It is an impossible combination of words. Its very existence, the possibility that it could be experienced as such would have led to the collapse of the Nazi regime, as a psychic dynamic (destructive tyranny, cruel and without guilt).

German guilt is another reality and deserves to be differentiated. We do not mention it here, except to distinguish it from Nazi guilt. German guilt related to the horrors of Nazism is an eminently depressive post-war guilt, although its awareness, expression and development has largely been made difficult by the violence and barbarity of the acts committed by the Nazis / Germans during the war - and by the identification of Nazis as Germans, which is probably still true decades later in the imagination of European nations. We have to consider the humiliation of the German defeat and the land taken and divided by the Allies and the German people themselves, who were also subject to huge levels of violence and destruction through bombing raids by the Allies. These factors together are at the root of a cloak of shame surrounding German guilt, limiting their psychic operability, that is, their ability to be a "psychic object" in transformation, as Bion would say. That is what the German writer WG Sebald showed in his important essay that helps us to understand the strange form of German guilt, or its silence (1999).

The mission of psychoanalysis is not to destroy Nazis. But it may be to recognize and fight Nazism or Nazi areas of functioning (or fascist, or tyrannical) in the human mind and human and social relations, and to help people oppressed by them - and inhabited by them. One moral of the story told here could be: While there is history there is Hope; while there is Hope, there is History - through human relationships and sensitivity. And through resistance and struggle against those who want to diminish them. 


\section{REFERENCIAS}

Arendt, H. (1951). As Origens do Totalitarismo. Lisboa: Dom Quixote, 2006. [in English: The Origins of Totalitarism]

Arendt, H. (1963). Eichmann em Jerusalém: Uma Reportagem sobre a Banalidade do Mal. Coimbra: Tenacitas, 2003. [in English: Eichmann in Jerusalem: A Report on the Banality of Evil]

Ciccone, A. (2003). La "Tyrannie-et-Soumission": Apports de Donald Meltzer.

Psychanalyse du Lyen Tyrannique (Ciccone et al). Paris: Dunod.

Fairbairn, W.R. (1940/1952). Factores Esquizóides da Personalidade. Estudos Psicanalíticos da Personalidade). Lisboa: Vega, 2000. [in English: Schizoid Factors in The Personality. Psychoanalytical Studies of the Personality]

Fairbairn, W.R. (1943/1952). O Recalcamento e a Reaparição dos Objectos Maus. Estudos Psicanalíticos da Personalidade. Lisboa: Vega, 2000. [in English: The Repression and the Return of Bad Objects. Psychoanalytical Studies of the Personality]

Fest, J. (1973). Hitler. New York: Vintage Books Edition, 1975.

Figueirôa, D. (2014). 1984 - 2666: Derivações Psicanalíticas sobre a Tirania e o Mal.

Clínica e Investigación Relacional, 8 (1): 115-124. Madrid: Ágora Relacional. [www.ceir.org.es] [English title would be: 1984 - 2666: Psychoanalytic Derivations on Tyranny and Evil]

Freud, S. (1913). Totem e Tabu. Edição Standard Brasileira das Obras Psicológicas Completas de Sigmund Freud, Vol. XIII. Rio de Janeiro: Imago, 1996. [in English: Totem and Taboo. The Standard Edition...]

Freud, S. (1930). O Mal-Estar na Civilização. Edição Standard Brasileira das Obras Psicológicas Completas de Sigmund Freud, Vol. XXI. Rio de Janeiro: Imago, 1996. [in English: Civilization and its Discontents. The Standard Edition...]

Grinberg, L. (1963). Culpa e Depressão. Lisboa: Climepsi, 2000. [in English: Guilt and Depression]

Grossman, D. (1986). Ver: Amor. Porto: Campo das Letras, 2004. [in English: See Under: Love]

Klein, M. (1946/1975). Notas Sobre Alguns Mecanismos Esquizóides. Inveja e Gratidão e Outros Trabalhos. Rio de Janeiro: Imago, 1991. [in English: Notes on Some Schizoid Mechanisms. Envy and Gratitude and Other Works]

Klein, M. (1957/1975). Inveja e Gratidão. Inveja e Gratidão e Outros Trabalhos. Rio de Janeiro: Imago, 1991. [in English: Envy and Gratitude. Envy and Gratitude and Other Works]

Meltzer, D. (1968). La Tyrannie. Psychanalyse du Lyen Tyrannique (Ciccone et al). Paris: Dunod, 2003.

Orange, D., Atwood, G., Stolorow, R. (1997). Working Intersubjectively: Contextualism in Psychoanalytic Practice. Hillsdale, NJ: Analytic Press.

Orwell, G. (1949). 1984.

Sebald, W.G. (1999). História Natural da Destruição. Lisboa: Teorema, 2006. [in English: On the Natural History of Destruction] 
Winnicott, D. (1966/1984). A Ausência de um Sentimento de Culpa. Privação e Delinquência (ed. C. Winnicott, R. Shepherd, M. Davis). São Paulo: Martins Fontes, 2002. [in English: The Absence of a Sence of Guilt. Deprivation and Deliquency]

Original recibido con fecha: 27/02/2016 Revisado: 27/02/2016 Aceptado: 28/02/2016 NOTAS:

US Holocaust Memorial Museum: www.ushmm.org 